\title{
PENGARUH IKLIM KERJA, MOTIVASI KERJA DAN KREATIVITAS PEGAWAI TERHADAP PRODUKTIVITAS KERJA PADA BADAN PENDAPATAN DAERAH PROVINSI BANTEN
}

\author{
Riri Nur Fitriana \\ Institut IImu Sosial dan Manajemen STIAMI \\ e-mail: zahra.montana210516@gmail.com
}

\begin{abstract}
Abstrak, Tujuan dari penelitian ini adalah untuk menganalisis besarnya pengaruh iklim kerja terhadap produktivitas kerja pegawai, untuk menganalisis besarnya pengaruh motivasi kerja terhadap produktivitas kerja pegawai, untuk menganalisis besarnya pengaruh kreativitas pegawai terhadap produktivitas kerja pegawai, dan untuk menganalisis besarnya pengaruh iklim kerja, motivasi kerja dan kreativitas pegawai terhadap produktivitas kerja pegawai. Teori iklim kerja yang digunakan dalam penelitian ini mengacu pada pendapat Wirawan, teori motivasi kerja yang digunakan dalam penelitian ini mengacu pada pendapat Sutrisno, teori kreativitas pegawai yang digunakan dalam penelitian ini mengacu pada pendapat Munandar, dan teori produktivitas kerja yang digunakan dalam penelitian ini mengacu pada pendapat Kasim

Metode penelitian yang digunakan adalah metode kuantitatif melalui penyebaran kuesioner, dengan jumlah populasi sebesar 78 dan sampelnya adalah 78 orang responden (sampel jenuh)

Berdasarkan hasil penelitian dengan menggunakan analisis regresi linier berganda dengan bantuan SPSS versi 24 menunjukan bahwa terdapat pengaruh signifikan iklim kerja terhadap produktivitas kerja pada Badan Pendapatan Daerah Provinsi Banten sebesar 9,8\%, terdapat pengaruh signifikan motivasi kerja terhadap produktivitas kerja pada Badan Pendapatan Daerah Provinsi Banten sebesar 57,4\%, terdapat pengaruh signifikan kretivitas kerja terhadap produktivitas kerja pada Badan Pendapatan Daerah Provinsi Banten sebesar 19,2\%, dan terdapat pengaruh signifikan iklim kerja, motivasi kerja dan kreativitas kerja secara bersama-sama terhadap produktivitas kerja pada Badan Pendapatan Daerah Provinsi Banten sebesar $86,4 \%$ sisanya $13,6 \%$ merupakan faktor lain yang tidak diteliti
\end{abstract}

Kata kunci : iklim kerja, motivasi kerja, kreativitas pegawai dan produktivitas kerja

\section{LATAR BELAKANG PENELITIAN}

Sebagaimana diketahui bahwa dalam suatu organisasi tidak bias terlepas dari unsur sumber daya manusia, baik yang berkedudukan sebagai pimpinan maupun sebagai bawahan yang merupakan tenaga pelaksana untuk mengendalikan factor-faktor sumber daya lain dalam suatu organisasi guna mencapai tujuan dan sasaran-sasarannya. Dalam setiap organisasi tidak terlepas dari sumber daya manusia. Kemampuan sumber daya manusia di tuntut memiliki kemampuan yang berkualitas untuk mendukung tercapainya tujuan dalam organisasi. memiliki sumberdaya manusia yang handal merupakan hal yang sangat berharga, bahkan merupakan asset yang sangat penting dalam memecahkan masalah-masalah.

Maju atau mundurnya kehidupan manusia, terwujud atau tidaknya citacita manusia tergantung pada sumber manusia pada kemampuannya untuk mengatur dan memanfaatkan sumber manusia yang ada dalam organisasi, termasuk sumber daya manusianya 
dengan lebih efisien, efektif dan produktif.

Pentingnya pengelolaan sumber daya manusia tertuju kepada efisiensi, efektifitas dan produktivitas. Kedudukan sumber daya manusia dalam wadah organisasai sangat strategis untuk meningkatkan produktivitas kerja. Dalam hal ini adalah pegawai yaitu orang-orang yang bergabung dalam organisasi. Pegawai yang memiliki pengaruh atau berperan aktif dalam organisasi akan merasa puas.

Pola perilaku hubungan manusia memperhatikan kesejahteraan bawahan, membuka saluran komunikasi, delegasi kekuasaan, mendengarkan bawahan. Kondisi demikian akan mewujudkan iklim organisasi yang sehat menyenangkan dan mendorong prakarsa dan tanggung jawab.

Organisasi pada dasarnya merupakan kumpulan dari beberapa orang yang terlibat dalam suatu organisasi. Organisasi merupakan suatu struktur koordinasi terencana yang formal, melibatkan dua orang atau lebih dalam rangka mencapai tujuan bersama.

Berdasarkan itu organisasi sebagai salah satu sistem yang terdiri dari unsur yaitu : (1) adanya tujuan (goals), (2) adanya manusia, dan (3) lingkungan organisasi. Unsur-unsur organisasi selanjutnya berpengaruh terhadap peranan dan perilaku dalam menciptakan suasana atau iklim organisasi.

Iklim organisasi adalah lingkungan manusia di dalam mana para pegawai organisasi melakukan pekerjaan mereka. Pengertian ini dapat mengacu lingkungan suatu departemen unit instansi atau suatu organisasi secara keseluruhan. Menyadari bahwa dalam organisasi terjadi saling berinteraksi sesama pegawai organisasi. Dalam setiap organisasi memiliki iklim kerja yang berbeda-beda, ada suasana kondusif, dinamis, sementara yang lain kurang bahkan tidak kondusif. Hal ini dipengaruhi faktor internal pegawai, iklim organisasi itu dan lingkungan eksternal organisasi. Perpaduan antara lingkungan internal dan pelaksanaan peran pada akhirnya mempengaruhi aktivitas, kepuasan, dan pertumbuhan organisasi baik buruknya iklim organisasi dapat menyebabkan perubahan perilaku pegawai menjadi negatif atau positif.

Keberhasilan organisasi pada umumnya diukur dari produktivitas dan efektivitas pelaksanaan tugas-tugas yang dilaksanakan dengan efektif, dari setiap pegawai yang ada. Sebaliknya bila produktivitas menurun dan para pegawai dinilai tidak efektif dalam jangka waktu tertentu. Kurangnya produktivitas kerja pegawai dapat disebabkan oleh beberapa hal yaitu pimpinan kurang dalam merespon ideide dan masukan-masukan dari bawahan, banyaknya tugas yang diberikan pimpinan yang terkadang selalu memaksakan kehendak dari pimpinan, bawahan tidak mempunyai kesempatan untuk mengeluarkan pendapat dan kreativitasnya, pengamalan budaya kerja yang dirasakan masih rendah, loyalitas dari pegawai dianggap masih kurang

Belum tercapainya efektivitas pelaksanaan tugas sebagai akibat kurangnya motivasi kerja dan kreativitas pegawai sudah barang tentu akan mengecewakan berbagai pihak, terutama bagi organisasi tersebut. Sehubungan dengan kondisi tersebut di atas, penulis mengadakan pengamatan terhadap satuan organisasi pemerintah yaitu Badan Pendapatan Daerah Provinsi Banten.

Saat organisasi memantapkan diri untuk mengadakan perubahan, hal utama yang akan menjadi fokus perubahan adalah perubahan di dalam 
internal organisasi tersebut Perubahan di dalam internal organisasi berkaitan dengan sumber daya manusia, kebijakan organisasi, ataupun keadaan situasional di organisasi tersebut.

Iklim kerja secara umum dapat dianggap sebagai karakteristik yang unik di sebuah organisasi. Iklim kerja merupakan hasil suatu tindakan yang telah ditempuh baik sadar atau tidak sadar oleh suatu kelompok yang berpengaruh terhadap tingkah laku anggota organisasi. Disisi lain, iklim kerja yang muncul dalam suatu organisasi merupakan faktor utama untuk menentukan pengembangan sikap dan perilaku para pegawai.

Masalah sumber daya manusia masih menjadi sorotan bagi organisasi untuk tetap dapat bertahan di era globalisasi. Suatu organisasi akan memiliki ketergantungan pada aspek sumber daya manusia. Sumber daya manusia memiliki faktor kendali yang dapat menentukan keberlangsungan suatu organisasi. Dengan meningkatkan kualitas sumber daya manusia diharapkan pegawai dapat bekerja secara produktif dan profesional sehingga kinerja yang dicapainya akan lebih memuaskan sesuai standar kerja yang ada diorganisasi.

Upaya organisasi untuk memperoleh sumber daya manusia yang berkualitas, maka perlu adanya suatu pengembangan sumber daya manusia. Investasi di dalam pengembangan sumber daya manusia merupakan pengeluaran yang ditujukan untuk memperbaiki kapasitas produktif dari manusia. Dengan manajemen sumber daya manusia yang baik, organisasi bisnis akan memiliki kekuatan kompetitif sehingga sumber keberhasila kompetitif tersebut menjadi lebih berdaya guna.

$$
\text { Salah satu pengembangan }
$$
sumber daya manusia yaitu melalui pelatihan. Pelatihan yang dimaksud yaitu mengacu pada upaya yang direncanakan oleh suatu organisasi untuk mempermudah pembelajaran pada pegawai tentang kompetensikompetensi yang berkaitan dengan pekerjaan. Kompetensi-kompetensi tersebut meliputi pengetahuan, keterampilan, atau perilaku yang sangat penting untuk keberhasilan kinerja pegawai

Bahwa setiap orang diharapkan agar lebih kreatif dalam berpikir dan melakukan sesuatu dengan cara yang berbeda. Kreativitas berasal dari individu yang mempunyai keahlian dan keterampilan berpikir kreatif berdasarkan pendidikan formal dan pengalaman masa lalu. Dengan adanya pelatihan serta kreativitas yang dimiliki oleh pegawai, maka seorang pegawai diharapkan mampu menghadapi tugas-tugas yang sangat kompleks serta dapat mencapai kinerja yang tinggi.

Berdasarkan

pengamatan penulis, sementara ini iklim kerja sangat mempengaruhi produktivitas kerja pegawai. Hal ini dapat dilihat dari seringnya pegawai datang terlambat, baik ketika apel pagi ataupun jam bekerja, seringnya pegawai keluar ketika jam-jam bekerja berlangsung, dengan alasan ada acara ataupun ada kepentingan-kepentingan pribadi yang harus dilakukan, pegawai sering memanfaatkan waktu bekerja hanya dengan bermain games ataupun hanya sekedar berbincang-bincang yang bukan hal pekerjaannya, pimpinan terkadang menganakemaskan seseorang ketika bekerja, kurang adanya ketegasan dari pimpian terhadap pegawai-pegawai yang lebih senior

Banyak faktor yang mempengaruhi kinerja seorang pegawai di lingkungan organisasi, salah satunya adalah faktor motivasi. Motivasi mengandung arti suatu 
kegiatan memberi dorongan untuk menggerakan orang lain maupun diri sendiri menuju tercapainya tujuantujuan yang telah ditetapkan. Salah satu tujuan yang hendak dicapai dari pemberian motivasi ini adalah terciptanya hasil kinerja yang maksimal dari seorang pegawai dalam mengerjakan setiap tugas atau pekerjaan yang diberikan dapat diselesaikan tepat pada waktunya. Motivasi yang diberikan kepada pegawai dapat berupa motivasi yang bersifat langsung maupun motivasi secara tidak langsung.

Sehubungan dengan hal tersebut maka pimpinan unit kerja atau instansi memiliki kewajiban untuk selalu memotivasi guna meningkatkan kinerjanya, dengan demikian kerja sama dan saling memahami tugas dan fungsi dari setiap unit kerja dapat berjalan dengan baik. Seberapa besar motivasi pegawai dalam melaksanakan setiap tugas atau pekerjaan yang menjadi tanggung jawabnya sangat tergantung pada keseimbangan antara produktivitas kerja dan kesejahteraan yang diperolehnya. Studi tentang motivasi merupakan usaha untuk mendapatkan jawaban atas segala perilaku manusia yang begitu komplek dalam keterkaitannya dengan kerja pegawai. Seorang pemimpin unit kerja atau instansi harus memilki visi kedepan yang dapat dipergunakan sebagai gambaran yang akan dicapai oleh instansi yang bersangkutan. Visi sangat diperlukan guna memotivasi pegawai tinggal mengarahkan kemana kemauan dan kemauan pegawai untuk berprestasi. Usaha untuk meningkatakan kinerja pegawai bukanlah pekerjaan yang mudah, karena kinerja pegawai dipengaruhi oleh banyak faktor diantaranya, skill, lingkungan kerja dan motivasi pimpinan dan disiplin kerja pegawai. Secara tegas kinerja pegawai yang paling dominan disebabkan oleh kesiapan mental seseorang untuk mengacu diri dan prestasi guna memperoleh segala yang diharapkan. Dengan demikian unsur-unsur kepuasan merupakan rangsangan untuk berprestasi.

Peranan motivasi dalam menunjang pemenuhan kebutuhan berprestasi sangat besar, dangan kata lain motivasi mempunyai hubungan yang positif terhadap prestasi kerja yang lebih baik dan sebaliknya. Motivasi tercakup konsep-konsep, seperti kebutuhan berprestasi, kebutuhan berafiliasi, kebiasaan, dan keingintahuan seseorang terhadap sesuatu. Ditinjau dari sumbernya, motivasi terbagi menjadi dua yaitu motivasi intrinsik dan motivasi ektrinsik. Motivasi intrinsik adalah motivasi yang timbulnya tidak memerlukan rangsangan dari luar karena memang telah ada dalam individu itu sendiri, yaitu sejalan dengan kebutuhannya. Sedangkan motivasi ektrensik timbul karena adanya rangsangan dari luar individu, misalnya dalam bidang pendidikan terdapat minat yang positif terhadap kegiatan pendidikan timbul karena melihat manfaatnya. Motif intrinsik lebih kuat dari motif ekstrinsik. Oleh karena itulah tidak heran jika pegawai mempunyai motivasi yang tinggi biasanya mempunyai kinerja yang tinggi pula.

Apabila ditarik garis penghubung anntara kondisi riil yang terjadi, maka menurut pengamatan sementara penulis, dapat diduga bahwa hal ini dilatarbelakangi beberapa faktor, salah satunya adalah kurangnya motivasi dari dalam diri pegawai itu sendiri. Motivasi meliputi : adanya dorongan untuk melakukan suatu kreatifitas dan inovasi dalam rangka peningkatan kinerja, adanya dorongan untuk mampu bekerja sama daripada berkompetisi, adanya motivasi untuk 
ikut serta dalam mencapai tugas dan fungsi instansi.

Kurangnya motivasi pada pegawai Dinas Pendapatan Daerah Provinsi Banten, ditandai oleh beberapa fenomena, diantaranya kurang ada kemauan untuk meningkatkan kapasitas dan prestasi, penyelesaian pekerjaan dilakukan terpaku pada cara-cara yang sudah biasa dilakukan, hanya menyenangi pekerjaan yang mudah, kurangnya kerjasama diantara pegawai

Dalam pengamatan awal ditemukan masih terdapat penyelesaian pekerjaan yang lamban, sehingga timbul teguran dari pimpinan yang lebih tinggi atau dari unit organisasi lain yang menanyakan penyelesaiaan atau jawaban atas surat-surat tersebut dan tugas-tugas lain yang belum terselesaikan secara tepat waktu. Kadang kala tugas-tugas rutin sering tertunda karena adanya tugas-tugas lain atau tambahan dari pimpinan yang lebih tinggi. Hal ini berdampak terhadap produktivitas kerja yang menurun
Badan
Pendapatan
Daerah

(BAPENDA) Provinsi Banten mempunyai fungsi sebagai pengelola pendapatan daerah salah satunya mengelola pajak daerah. Seperti yang tercantum dalam Undang-undang Republik Indonesia Nomor 28 tahun 2009 tentang pajak daerah dan retribusi daerah, yang terdiri dari : Pajak Kendaraan Bermotor (PKB), Bea Balik Nama Kendaraan Bermotor (BBNKB), Pajak Bahan Bakar Kendaraan Bermotor (PBBKB), Pajak Air Permukaan (P-AP), dan Pajak Rokok adapun target dan realisasinya Pajak Daerah Provinsi Banten untuk Tahun Anggaran 2017 diuraikan dalam tabel dibawah ini :

Tabel 1 Target dan Realisasi Pajak Daerah Provinsi Banten

Tahun Anggaran 2017 (UnAudit)

\begin{tabular}{|c|c|c|c|c|c|}
\hline No & Uraian Penerimaan & $\begin{array}{c}\text { Target Pajak } \\
\text { Daerah }\end{array}$ & $\begin{array}{c}\text { Realisasi Pajak } \\
\text { Daerah }\end{array}$ & $+1-$ & $\%$ \\
\hline 1 & Pajak Kendaraan Bermotor & 2.051 .000 .000 .000 & 2.115 .880 .876 .200 & 64.880 .876 .200 & 103,16 \\
\hline 2 & Bea Balik Nama Kendaraan Bermotor & 1.959 .166 .000 .000 & 1.969 .752 .930 .203 & 10.586 .930 .203 & 100,54 \\
\hline 3 & Pajak Bahan Bakar Kendaraan Bermotor & 746.200 .000 .000 & 785.870 .170 .379 & 39.670 .170 .379 & 105,32 \\
\hline 4 & Pajak Air Permukaan & 33.538 .000 .000 & 34.485 .123 .339 & 947.123 .339 & 102,82 \\
\hline 5 & Pajak Rokok & 715.667 .000 .000 & 581.339 .643 .887 & $(134.327 .356 .113)$ & 81,23 \\
\hline & Jumlah & 5.505 .571 .000 .000 & 5.487 .328 .744 .008 & (18.424.255.992) & 99,67 \\
\hline
\end{tabular}

Sumber : Laporan Kinerja Instansi Pemerintah (LKIP) Badan Pendapatan Daerah Tahun Anggaran 2017

Pada tabel diatas bahwa prosentase realisasi pajak daerah keseluruhan sebesar $99,67 \%$ artinya pajak daerah yang diperoleh pada tahun anggaran 2017 tidak mencapai target. Hal ini dikarenakan tidak tercapainya realisasi pajak rokok (realisasi capaian pajak rokok pada TW.II telah memacu Badan Pendapatan Daerah Provinsi Banten untuk menaikan target pada P-APBD Tahun anggaran 2017.

Berdasarkan data diatas peneliti menduga bahwa sementara ini masih kurangnya produktivitas pegawai disebabkan oleh lambannya penyelesaian kerja serta tugas lain yang harus segera diselesaikan erat kaitannya dengan kondisi yang ada di lingkungan Badan Pendapatan Daerah Provinsi Banten. Pegawai yang sering datang terlambat, dapat disebabkan karena kondisi tempat tinggal dengan tempat kerja yang sangat jauh, namun di sisi lain, jauhnya tempat tinggal bukanlah satu-satunya alasan yang dijadikan untuk datang terlambat, namun penulis menduga karena faktor ketaatan yang kurang, kurangnya pimpinan untuk memberikan dorongan agar pegawai datang tepat waktu dan memberikan sanksi terhadap pegawai yang indisipliner. Begitu pula terhadap pegawai yang sering meninggalkan tempat kerja, pulang sebelum waktunya dan tindakan-tindakan 
indisipliner lainnya, menurut dugaan penulis hal tersebut tidak terlepas dari hubungan antara pegawai, pimpinan dan lingkungan organisasinya.

Selain itu penulis menduga, bahwa terdapat pegawai yang merasa jenuh dan bosan, karena ide-ide, prakarsa dan kemampuan yang ada tidak dapat disalurkan pada unit organisasinya, sehingga pegawai tersebut menyalurkan ide, bakat dan kemampuannya di tempat lain.

Sehubungan dengan hal tesebut, penulis menduga bahwa produktivitas pelaksanaan tugas Aparatur Sipil Negara di Badan Pendapatan Daerah Provinsi Banten sangat dipengaruhi oleh iklim kerja khususnya pada situasi pekerjaan, korrdinasi antar pegawai, di mana hal tersebut sangat dipengaruhi visi, wawasan masa depan organisasi, komitmen terhadap organisasi,, kemampuan, kreativitas pegawai, situasi lingkungan kerja di satu pihak serta kuantitas/kualitas tenaga personil sarana dan prasarana, iklim dan budaya kerja, pencapaian sasaran di lain pihak.

Dengan memperhatikan uraian di atas, maka dalam penelitian ini akan memusatkan kajian kepada "Pengaruh Iklim Kerja, Motivasi Kerja dan Kreativitas Pegawai Terhadap Produktivitas Kerja Pegawai Pada Badan Pendapatan Daerah Provinsi Banten"

\section{KAJIAN LITERATUR Iklim Kerja}

Para ahli mengartikan bahwa iklim organisasi sebagai suatu unsur fisik, dimana iklim dapat sebagai suatu atribusi dari organisasi atau sebagai suatu atribusi dari persepsi individu sendiri. Menurut Simamora (2010:81) bahwa iklim organisasi adalah lingkungan internal atau psikologi organisasi. Iklim organisasi mempengaruhi praktik dan kebijakan Sumber Daya Manuasia yang diterima oleh anggota organisasi. Perlu diketahui bahwa setiap organisasi akan memiliki iklim organisasi yang berbeda. Keanekaragaman pekerjaan yang dirancang di dalam organisasi, atau sifat individu yang ada akan menggambarkan perbedaan tersebut. Menurut Wirawan (2012:121) bahwa iklim organisasi merupakan kualitas lingkungan internal yang secara relatif terus berlangsung, dialami oleh anggota organisasi, mempengaruhi perilaku setiap anggotanya.

Reichers dan Scheinder (1990, dalam Siswanto, 2012) menyatakan iklim kerja diartikan sebagai persepsi tentang kebijakan,praktek-praktek dan prosedur-prosedur organisasional yang dirasa dan diterima oleh individuindividu dalam organisasi, ataupun persepsi individu terhadap tempatnya bekerja. Individu dalam suatu organisasi menganggap iklim kerja merupakan sebuah atribut, dimana atribut ini digunakan dalam perwujudan bagi keberadaan mereka di dalam organisasi. Iklim kerja berada pada tingkat individu dan organisasi, disaat iklim kerja masuk pada tatanan individu, maka hal ini disebut iklim psikologikal (psychological climate) sedangkan apabila penilaian terhadap iklim tersebut telah irasakan oleh banyak individu di dalam sebuah organisasi maka akan disebut iklim kerja organisasional.

Berbagai macam definisi tentang iklim kerja dapat menjadi pemahaman bahwa iklim kerja erat kaitannya dengan tiga hal: lingkungan internal organisasi, individu dalam organisasi, dan karakteristik khas antara satu organisasi dengan organisasi lainnya (Siswanto, 2012). Dari pendapat di atas maka dapat dikatakan bahwa iklim organisasi merupakan suatu konsep yang menggambarkan tentang kualitas lingkungan internal organisasi yang mempengaruhi prilaku anggota organisasi dalam melaksanakan 
pekerjaannya. Di dalam praktiknya, penting untuk menciptakan sebuah iklim kerja yang tepat dan menyediakan sumber daya yang efektif sehingga menjauhkan organisasi dari hal-hal negatif dan dapat merangsang motivasi pegawai untuk terus bekerja. Sumber daya pekerjaan yang terkait dengan hal seperti kerja keras dan teamwork sangat membantu untuk menghasilkan tujuan dan cita-cita organisasi.

Untuk mengukur iklim organisasi terdapat 6 dimensi yang diperlukan Wirawan (2012:71), yaitu :

1. Struktur (Structure)

Struktur organisasi merefleksikan persaaan organissasi secara baik dan mempunyai peran dan tanggung jawab yang jelas dalam lingkungan organisasi. Struktur tinggi jika nggota organisasi merasa pekerjaan mereka didefenisikan secara baik. Struktur rendah jika mereka merasa tidka ada kejelasan mengenai siapa yang melakukan tugas dan mempunyai kewenangan mengambil keputusan

2. Standar-standar (Standards)

Standar-standar dalam suatu organisasi mengukur perasaan tekanan untuk meningkatkan kinerja dan derajat kebanggan yang dimiliki oleh anggota organisasi dalam melakukan pekerjaan dengan baik. Standarstandar yang tinggi artinya anggota organisasi selalu berupaya mencari jalan untuk meningkatkan kinerja. Standar-standar rendah merefleksikan harapan yang lebih rendah untuk kinerja. Persepsi tanggung jawab yang tinggi menunjukan bahwa anggota organisasi merasa didorong untuk memecahkan problemnya sendiri. Tanggung jawab rendah menunjukkan bahwa pengambilan resiko dan percobaan terhadap pendekatan baru tidak diharapkan.

3. Tanggung Jawab (Responsibility)

Tanggung jawab merefleksikan perasaan pegawai bahwa mereka menjauh "bos diri sendiri" dan tidak memerlukan keputusannya dilegitimasi oleh anggota organisasi lainnya. Persepsi tanggung jawab yang tinggi menunjukkan bahwa anggota organisasi merasa didorong untuk memecahkan problemnya sendiri. Tanggung jawab rendah menunjukkan bahwa pengambilan resiko dan percobaan terhadap pendekatan baru tidak diharapkan.

4. Penghargaan (Recognition)

Penghargaan mengindikasikan bahwa anggota organisasi merasa dihargai jika mereka dapat menyelesaikan tugas secara baik. Penghargaan tinggi merupakan ukuran penghargaan dihadapkan dengan kritik dan hukuman penyelesaian pekerjaan, iklim kerja yang menghargai kinerja berkarakteristik keseimbangan antara imbalan dan kritik. Penghargaan rendah artinya penyelesaian pekerjaan dengan baik diberi imbalan secara tidak konsisten.

5. Dukungan (Support)

Dukungan yang positif dari pimpinan dan para pegawai lainnya akan menciptakan situasi kerja yang kondusif. Selain itu dukungan juga memunculkan semangat tim para pekerja sehingga mereka dapat saling mempercayai dan saling membantu, serta adanya hubungan baik antar pekerja didalam lingkungan kerja.

6. Komitmen (Commitment)

Komitmen merefleksikan perasaan bangga anggota terhadap organisasinya dan derajat keloyalan terhadap pencapaian tujuan organisasi. Perasaaan komitmen artinya pegawai 
berpartisipasi terhadap organisasi dan tujuan

\section{Motivasi Kerja}

Menurut Flippo dalam Hasibuan (2007:46) mengatakan bahwa motivasi adalah keahlian dalam mengarahkan pegawai dan organisasi agar mau bekerja secara berhasil sehingga keinginan para pegawai dan tujuan organisasi sekaligus tercapai.

Pengertian motivasi seperti dikemukakan oleh Wexley \& Yukl (1977) yang dikutip oleh Sutrisno (2009:110) adalah pemberian atau penimbulan motif atau dapat pula diartikan sebagai hal atau keadaan menjadi motif. Jadi, motivasi adalah sesuatu yang menimbulkan semangat atau dorongan kerja.

Salah satu yang populer dari teori kebutuhan yang menyangkut motivasi kerja adalah teori Abraham Maslow yang berbicara mengenai individu yang mempunyai kebutuhan yang bertingkat-tingkat. Menurut teori ini, setelah kebutuhan pokoknya seperti pangan, perlindungan dan keselamatan terpenuhi, maka seseorang akan segera merasakan kebutuhan yang lebih tinggi tingkatnya seperti rasa dicintai dan mencintai, rasa dihargai dan rasa ingin menampilkan kemampuannya.

Menurut Sutrisno (2009:116-120) faktor-faktor yang mempengaruhi motivasi karyawan antara lain :

1. Faktor intern

a. Keinginan untuk hidup

b. Keinginan untuk dapat memiliki

c. Keinginan untuk memperoleh penghargaan

d. Keinginan untuk memperoleh pengakuan

e. Keinginan untuk berkuasa

2. Faktor ektern

a. Kondisi lingkungan kerja

b. Kompensasi yang memadai

c. Supervisi yang baik

d. Adanya jaminan pekerjaan e. Status dan tanggung jawab

f. Peraturan yang fleksibel

\section{Kreativitas Pegawai}

Munandar (2011) mendefinisikan kreativitas sebagai kemampuan untuk membuat kombinasi baru berdasarkan data, informasi, atau unsur-unsur yang ada. Lebih lanjut dijelaskan pula bahwa apa yang diciptakan tidak perlu hal-hal yang baru sama sekali, tetapi merupakan gabungan (kombinasi) dari hal-hal yang sudah ada sebelumnya.

Menurut Guilford

(1959) membedakan ciri-ciri orang kreatif dalam dua kelompok, yaitu ciri-ciri aptitude dan ciri-ciri non-aptitude. berpendapat bahwa agar tindakan kreatif dapat terwujud tidak hanya diperlukan terpenuhinya ciri-ciri kognitif yang dimiliki seseorang, tetapi juga ciri-ciri kepribadian tertentu penting untuk dimiliki (dalam Munandar, 2011).

1. Ciri-ciri aptitude

Ciri-ciri aptitude ialah ciri-ciri yang berhubungan dengan kognisi, dengan proses berpikir.

Berikut yang termasuk kedalam kemampuan berpikir kreatif :

a. Keterampilan berpikir lancar

Yaitu mencetuskan banyak gagasan, jawaban, penyelesaian masalah atau pertanyaan; Memberikan banyak cara atau saran untuk melakukan berbagai hal; Selalu memikirkan lebih dari satu jawaban.

b. Keterampilan berpikir luwes (fleksibel)

Yaitu : Menghasilkan gagasan, jawaban, atau pertanyaan yang bervariasi; Dapat melihat suatu masalah dari sudut pandang yang berbeda; Mencari banyak alternative atau arah yang berbeda-beda; Mampu mengubah cara pendekatan atau cara pemikiran. 
c. Keterampilan berpikir orisinal Yaitu : Mampu melahirkan ungkapan yang baru dan unik; Memikirkan cara yang tidak lazim untuk mengungkapkan diri; Mampu membuat kombinasi-kombinasi yang tidak lazim dari bagian-bagian atau unsur-unsur.

d. Keterampilan memperinci (mengelaborasi)

Yaitu : Mampu memperkaya dan mengembangkan suatu gagasan atau produk; Menambahkan atau memperinci detil-detil dari suatu obyek,gagasan, atau situasi sehingga menjadi lebih menarik.

e. Keterampilan menilai (mengevaluasi)

Yaitu : Menentukan patokan penilaian sendiri dan menentukan apakah suatu pertanyaan benar, suatu rencana sehat, atau suatu tindakan bijaksana; Mampu mengambil keputusan terhadap situasi yang terbuka; Tidak hanya mencetuskan gagasan, tetapi juga melaksanakannya.

2. Ciri-ciri afektif (non-aptitude)

a. Rasa ingin tahu

Yaitu : Selalu terdorong untuk mengetahui lebih banyak; Mengajukan banyak pertanyaan; Selalu memperhatikan orang, obyek, dan situasi; Peka dalam pengamatan dan ingin mengetahui/meneliti.

b. Bersifat imajinatif

Yaitu : Mampu memperagakan atau membayangkan hal-hal yang tidak atau belum pernah terjadi; Menggunakan khayalan, tetapi mengetahui perbedaan antara khayalan dan kenyataan.

c. Merasa tertantang oleh kemajemukan
Yaitu : Terdorong untuk mengatasi masalah yang sulit; Merasa tertantang oleh situasisituasi yang rumit; Lebih tertarik pada tugas-tugas yang sulit.

d. Sifat berani mengambil risiko Yaitu : Berani memberikan jawaban meskipun belum tentu benar; Tidak takut gagal atau mendapat kritik; Tidak menjadi ragu-ragu karena ketidakjelasan, hal-hal yang tidak konvensional atau yang kurang berstruktur.

e. Sifat menghargai

Yaitu : Dapat menghargai bimbingan dan pengarahan dalam hidup; menghargai kemampuan dan bakat-bakat sendiri yang sedang berkembang

\section{Produktivitas Kerja}

Untuk memberikan definisi produktivitas, telah banyak para ahli yang memberikan pengertian menurut sudut pandangnya masing-masing tujuan dari masing-masing organisasi, dimana organisasi pemerintah yang berfokus untuk memberikan layanan kepada masyarakat, sedangkan organisasi swasta bertujuan untuk mencari keutungan. Disisi lain produktivitas dapat ditinjau produktivitas organisasi disatu pihak dan produktivitas masing-masing pegawai di lain pihak.

Dalam ilmu ekonomi, produktivitas merupakan nisbah atau rasio antara hasil kegiatan (output, keluaran) dan segala pengorbanan (biaya) untuk mewujudkan hasil tersebut (output, masukan) (Kussriyanto, 2010:1)

Menurut Hasibuan (2011:126127) mengemukakan bahwa produktivitas adalah perbandingan antara keluaran (output) dengan masukan (input). Jika produktivitas naik ini hanya dimungkinkan oleh 
adanya peningkatan efiseinsi (waktubahan-tenaga) dan sistem kerja, teknik produksi dan adanya peningkatan keterampilan dari tenaga kerjanya.

$$
\text { Menurut Kasim (2008:20) }
$$

menyatakan bahwa konsep produktivitas disektor bisnis berbeda dengan sektor publik (pemerintah) karena ada perbedaan pokok yang mandasar. la mengutip pendapat Balk (1976) yang mengatakan bahwa produktivitas dalam organisasi pemerintah juga harus diukur dari segi kualitas hasil yang di persembahkannya kepada masyarakat, yaitu sampai seberapa jauh hasil tersebut sesuai dengan standar yang diinginkan. Standar ini meliputi ciri-ciri dari output, misalnya beberapa unit atau event yang dihasilkan, bagaimana jadwal penyelesaiannya (timeliness), dan seberapa jauh kemampuan dari klien atau masyarakat yang dilayaninya. Menurut Kasim (2008:22), harus diperhatikan bahwa unsur kualitas tidak tercermin dari rasio output rerhadap input organisasi pemerintahan karena indah ada harga pasarnya. Karena itu perlu memasukan kriteria tentang standar dari output kedalam perhitungan produktivitas organisasi disektor publik, sehingga persamaan produktivitas adalah sbb:

Produktivitas $=$ efisien an efektivitas

Produktivitas $=\mathrm{O} / \mathrm{I}+\mathrm{O} / \mathrm{S}$

Dimana,

$\mathrm{O}=$ Output

I = Input

$\mathrm{S}=$ Standar

Untuk itu aspek-aspek yang mempengaruhi tingkat produktivitas kerja harus diketahui sehingga dapat dijadikan sebagai indikator. Kasim (2008:48) menyatakan aspek yang menggambarkan peningkatan produktivitas kerja pegawai, yaitu :

1. Kemampuan kerja pegawai a. Kesesuaian kualitas hasil kerja dengan rencana

b. Kesesuaian dalam melaksanakan kerja dengan prosedur

c. Kesalahan dalam melaksanakan pekerjaan

2. Sanksi dari pimpinan

3. Sikap kerja pegawai

a. Keberanian dalam mengambil resiko dalam melaksanakan tugasnya

b. Kemauan untuk memperbaiki hasil kerja

4. Penggunaan jam kerja

a. Penyelesaian pekerjaan sesuai dengan waktu yang ditentukan

b. Penggunaan / pemanfaatan jam istirahat untuk melakukan pekerjaan

c. Pemanfaatan waktu kerja secara optimal

\section{METODE PENELITIAN}

Metode yang digunakan adalah metode kuantitatif, dengan rumusan masalah asosiatif dan pendekatan atau kerangka pemikiran paradigma ganda dengan tiga variabel independen yang diduga sebagai variabel paling dominan mempengaruhi produktivitas kerja, yaitu iklim kerja, motivasi kerja dan kreativitas kerja

Populasi dalam penelitian ini adalah seluruh pegawai Badan Pendapatan Daerah Provinsi Banten yang berjumlah 80 orang. Jumlah sampel setelah dikurangi Kepala Badan Pendapatan Daerah Provinsi Banten dan peneliti jadi total sampel sebanyak 78 orang. 
HASIL

PENELITIAN

DAN

PEMBAHASAN

1. Pengaruh iklim kerja terhadap produktivitas kerja pada Badan Pendapatan Daerah Provinsi Banten

Dari deskripsi data setelah dilakukan analisis korelasi diperoleh nilai korelasi sebesar 0,744 dan koefisien determinasi sebesar 9,8\%, setelah dilakukan pengujian dengan program SPSS versi 24 terbukti bahwa koefisien korelasi tersebut signifikan. Hal ini berarti bahwa terdapat pengaruh iklim kerja terhadap produktivitas kerja pada Badan Pendapatan Daerah Provinsi Banten

Setelah dilakukan pengujian liniearitas garis regresi dengan menggunakan program SPSS diperoleh bahwa garis regresi linier. Dari pengujian signifikansi koefisien regresi yang juga dilakukan dengan program SPSS tersebut diperoleh bahwa koefisien regresi tersebut signifikan, yang berarti benar bahwa terdapat pengaruh yang signifikan iklim kerja terhadap produktivitas kerja pada Badan Pendapatan Daerah Provinsi Banten

Nilai Sig $=0,049<0,05$ dan $t_{\text {hitung }} 2,006>t_{\text {tabel }} 1,671$, maka $\mathrm{H}_{0}$ di tolak yang berarti terdapat pengaruh yang signifikan iklim kerja $\left(X_{1}\right)$ terhadap produktivitas kerja $(\mathrm{Y})$ pada Badan Pendapatan Daerah Provinsi Banten

Menurut sintesis teori yang ada di bab II, Hasil penelitian ini sesuai dengan pernyataan menurut Wirawan (2012:71) dengan dimensi antara lain struktur (structure), standar-standar (standards), tanggung jawab (responsibility), penghargaan (recognition), dukungan (support), komitmen (commitment)
Dari informasi kuantitatif dan teori tersebut peneliti berkesimpulan bahwa iklim kerja berpengaruh signifikan terhadap produktivitas kerja ( $\mathrm{Y}$ ) pada Badan Pendapatan Daerah Provinsi Banten.

\section{Pengaruh motivasi kerja terhadap produktivitas kerja pada Badan Pendapatan Daerah Provinsi Banten}

Dari deskripsi data setelah dilakukan analisis korelasi diperoleh nilai korelasi sebesar 0,908 dan koefisien determinasi sebesar $57,4 \%$, setelah dilakukan pengujian dengan program SPSS versi 24 terbukti bahwa koefisien korelasi tersebut signifikan. Hal ini berarti bahwa terdapat pengaruh motivasi kerja terhadap produktivitas kerja pada Badan Pendapatan Daerah Provinsi Banten

Setelah dilakukan pengujian liniearitas garis regresi dengan menggunakan program SPSS diperoleh bahwa garis regresi linier. Dari pengujian signifikansi koefisien regresi yang juga dilakukan dengan program SPSS tersebut diperoleh bahwa koefisien regresi tersebut signifikan, yang berarti benar bahwa terdapat pengaruh yang signifikan motivasi kerja terhadap produktivitas kerja pada Badan Pendapatan Daerah Provinsi Banten

Nilai Sig $=0,000<0,05$ dan $t_{\text {hitung }} 8,630>t_{\text {tabel }} 1,671$, maka $\mathrm{H}_{0}$ di tolak yang berarti terdapat pengaruh yang signifikan motivasi kerja $\left(X_{2}\right)$ terhadap produktivitas kerja ( $\mathrm{Y}$ ) pada Badan Pendapatan Daerah Provinsi Banten

Menurut sintesis teori yang ada di bab II, Hasil penelitian ini sesuai dengan pernyataan menurut Sutrisno (2009:116-120) dengan 
dimensi faktor internal dan faktor eksternal

Dari informasi kuantitatif dan teori tersebut peneliti berkesimpulan bahwa motivasi kerja berpengaruh signifikan terhadap produktivitas kerja pada Badan Pendapatan Daerah Provinsi Banten

\section{Pengaruh kreativitas kerja terhadap produktivitas kerja pada Badan Pendapatan Daerah Provinsi Banten}

Dari deskripsi data setelah dilakukan analisis korelasi diperoleh nilai korelasi sebesar 0,827 dan koefisien determinasi sebesar 19,2\%, setelah dilakukan pengujian dengan program SPSS versi 24 terbukti bahwa koefisien korelasi tersebut signifikan. Hal ini berarti bahwa terdapat pengaruh kreativitas kerja terhadap produktivitas kerja pada Badan Pendapatan Daerah Provinsi Banten

Setelah dilakukan pengujian liniearitas garis regresi dengan menggunakan program SPSS diperoleh bahwa garis regresi linier. Dari pengujian signifikansi koefisien regresi yang juga dilakukan dengan program SPSS tersebut diperoleh bahwa koefisien regresi tersebut signifikan, yang berarti benar bahwa terdapat pengaruh yang signifikan kreativitas kerja terhadap produktivitas kerja pada Badan Pendapatan Daerah Provinsi Banten

$$
\text { Nilai Sig }=0,003<0,05 \text { dan }
$$
$t_{\text {hitung }} 3,056>t_{\text {tabel }} 1,671$, maka $\mathrm{H}_{0}$ di tolak yang berarti terdapat pengaruh yang signifikan kreativitas kerja $\left(X_{3}\right)$ terhadap produktivitas kerja $(\mathrm{Y})$ pada Badan Pendapatan Daerah Provinsi Banten
Menurut sintesis teori yang ada di bab II, Hasil penelitian ini sesuai dengan pernyataan menurut Munandar (2011:56) dengan dimensi antara lain ciri-ciri aptitude, dan ciri-ciri afektif (non-aptitude)

Dari informasi kuantitatif dan teori tersebut peneliti berkesimpulan bahwa kreativitas kerja berpengaruh signifikan terhadap produktivitas kerja pada Badan Pendapatan Daerah Provinsi Banten

4. Pengaruh iklim kerja, motivasi kerja dan kreativitas kerja secara bersama-sama terhadap produktivitas kerja pada Badan Pendapatan Daerah Provinsi Banten

Dari deskripsi data setelah dilakukan analisis korelasi diperoleh nilai korelasi sebesar 0,929 dan koefisien determinasi sebesar $86,4 \%$, setelah dilakukan pengujian dengan program SPSS versi 24 terbukti bahwa koefisien korelasi tersebut signifikan. Hal ini berarti bahwa terdapat pengaruh iklim kerja, motivasi kerja dan kreativitas kerja secara bersamasama terhadap produktivitas kerja pada Badan Pendapatan Daerah Provinsi Banten

Sedangkan dari analisis regresi diperoleh persamaan garis regresi

$\hat{Y}=3,703+0,134 X_{1}+0,517 X_{2}+0,206 X_{3}$

Nilai konstanta $=3,703$ menunjukan bahwa dengan iklim kerja, motivasi kerja dan kreativitas kerja, maka produktivitas kerja pegawai pada Badan Pendapatan Daerah Provinsi Banten dapat meningkat, sedangkan nilai regresi sebesar 0,134, 0,517 dan 0,206 menunjukan bahwa terdapat terdapat pengaruh positif iklim kerja, motivasi kerja dan kreativitas kerja secara bersama-sama 
terhadap produktivitas kerja pada Badan Pendapatan Daerah Provinsi Banten. Angka koefisien regresi tersebut juga menunjukan bahwa setiap kenaikan satu nilai iklim kerja maka akan terdapat kenaikan produktivitas kerja pada Badan Pendapatan Daerah Provinsi Banten sebesar 0,134, untuk motivasi kerja setiap ada kenaikan satu nilai motivasi kerja maka akan terdapat kenaikan produktivitas kerja pada Badan Pendapatan Daerah Provinsi Banten sebesar 0,517, sedangkan untuk kreativitas kerja setiap ada kenaikan satu nilai kreativitas kerja maka akan terdapat kenaikan produktivitas kerja pada Badan Pendapatan Daerah Provinsi Banten sebesar 0,206. Semuanya dalam keadaan cateris paribus.

Setelah dilakukan pengujian liniearitas garis regresi dengan menggunakan program SPSS diperoleh bahwa garis regresi linier. Dari pengujian signifikansi koefisien regresi yang juga dilakukan dengan program SPSS tersebut diperoleh bahwa koefisien regresi tersebut signifikan, yang berarti benar bahwa terdapat pengaruh yang signifikan iklim kerja, motivasi kerja dan kreativitas kerja secara bersama-sama terhadap produktivitas kerja pada Badan Pendapatan Daerah Provinsi Banten

$$
\text { Nilai Sig }=0.000<0,05 \text { dan }
$$

$F_{\text {hitung }} 156,624>F_{\text {tabel }}$ 3,58, maka $\mathrm{H}_{0}$ di tolak yang berarti bahwa koefisien regresi tersebut signifikan. Berarti bahwa terdapat pengaruh signifikan iklim kerja, motivasi kerja dan kreativitas kerja secara bersama-sama terhadap produktivitas kerja pada Badan Pendapatan Daerah Provinsi Banten
Menurut sintesis teori yang ada di bab II, Hasil penelitian ini sesuai dengan pernyataan menurut Kasim (2008:48) dengan dimensi antara lain kemampuan kerja pegawai, sikap kerja pegawai, dan penggunaan jam kerja

Dari informasi kuantitatif dan teori tersebut peneliti berkesimpulan bahwa iklim kerja, motivasi kerja dan kreativitas kerja secara bersama-sama berpengaruh signifikan terhadap produktivitas kerja pada Badan Pendapatan Daerah Provinsi Banten

\section{KESIMPULAN}

Berdasarkan hasil analisis data yang telah dilakukan terhadap seluruh data yang diperoleh, maka dapat diambil kesimpulan sebagai berikut :

1. Terdapat pengaruh signifikan iklim kerja terhadap produktivitas kerja pada Badan Pendapatan Daerah Provinsi Banten sebesar 9,8\%

2. Terdapat pengaruh signifikan motivasi kerja terhadap produktivitas kerja pada Badan Pendapatan Daerah Provinsi Banten sebesar $57,4 \%$

3. Terdapat pengaruh signifikan kretivitas kerja terhadap produktivitas kerja pada Badan Pendapatan Daerah Provinsi Banten sebesar 19,2\%

4. Terdapat pengaruh signifikan iklim kerja, motivasi kerja dan kreativitas kerja secara bersama-sama terhadap produktivitas kerja pada Badan Pendapatan Daerah Provinsi Banten sebesar 86,4\% sisanya $13,6 \%$ merupakan faktor lain yang tidak diteliti

\section{SARAN}

Sesuai dengan hasil penelitian, maka beberapa saran potensial penulis ajukan sebagai berikut :
1. Pimpinan
Badan
Pendapatan 
Daerah Provinsi Banten agar memberikan dukungan yang positif kepada para pegawai agar tercipta situasi kerja yang kondusif yang berdampak pada peningkatan produktivitas kerja

2. Badan Pendapatan Daerah Provinsi Banten memberikan penghargaan atau timbal balik untuk setiap pekerjaan yang telah dilakukan dengan baik agar pegawai termotivasi dalam menyelesaikan pekerjaan

3. Pegawai Badan Pendapatan Daerah Provinsi Banten agar diberikan pelatihan supaya kreativitas kerja dan imajinasi pegawai dalam menyelesaikan pekerjaan atau tugas menjadi lebih baik lagi, yang diharapkan berdampak pada peningkatan produktivitas yang optimal

4. Dalam melaksanakan pegawai Badan Pendapatan Daerah Provinsi Banten agar selalu menyesuaikan serta melaksanakan pekerjaan sesuai dengan prosedur yang tercantum dalam tupoksi sehingga produktivitas pegawai dapat tercapai secara optimal

\section{DAFTAR PUSTAKA}

As'ad, M. 2012. Psikologi Industri:Seri Sumber Daya Manusia. Yogyakarta : Liberty.

Arikunto, Suharsimi. 2008. Manajemen Penelitian. Jakarta. Rineka Cipta

........,2010. Manajemen Peneltian. Jakarta. Rineka Cipta.

Gibson, J. L., J. M. Ivancevich \& J. H. Donnelly. 2008. Organizations : Behavior, Structure and Processes. New York. Mc GrawHill Companies, Inc.

Hasibuan, Malayu SP. Manajemen Sumber Daya Manusia. Jakarta. CV Haji Masagung. 2011

Haryadi, Hendi. 2009. Administrasi Perkantoran untuk Manajer \& Staff. Jakarta : Visimedia.
Manullang, M. 2012. Dasar-dasar Manajemen. Yogyakarta : Gadjah Mada University Press.

Munandar, A. S. 2011. Psikologi Industri dan Organisasi. Jakarta: UI-Press.

Nawawi, Hadari. 2011. Manajemen Sumber Daya Manusia. Yogyakarta : Gadjah Mada University Press

Notoatmodjo, $\quad$ Soekidjo. 2009. Pengembangan Sumber Daya Manusia. Jakarta : PT. Rineka Cipta.

Oldham, G.R. and Cummings, A. (1996). Employee creativity: personal and contextual factors at work. Academy of Management Journal, Vol. 39, pp. 607-34.

Sedarmayanti. 2010. Manajemen Sumber Daya Manusia, Reformasi Birokrasi dan Manajemen Pegawai Negeri Sipil. Bandung : PT. Refika Aditama.

Simamora, Hendry 2010. Manajemen Sumber Daya Manusia, Cetakan 3. Yogyakarta. Bagian Penerbitan Sekolah Tinggi Imu Ekonomi

Sugiyono. 2012. Metode Penelitian Administrasi. Bandung : CV. Alfabeta.

Triguno, 2008. Budaya Kerja : Menciptakan Lingkungan yang Kondusif untuk Meningkatkan Produktivitas Kerja. Jakarta : PT. Golden Terayon Press.

.2012. Budaya Kerja, Meningkatkan lingkungan yang kondusif untuk Meningkatkan Produktivitas kerja. Jakarta : Golden Terayon press

Wirawan. 2012. Budaya dan Iklim Organisasi. Jakarta : Salemba Empat.

\section{Jurnal :}

Fauziyah, Ani. 2005. Pengaruh pengawasan kerja dan disiplin 
kerja terhadap produktivitas kerja karyawan bagian produksi pelintingan di Perusahaan Rokok Kretek Sukun MC. Wartono Kudus. Jurnal

Legawati Kartika. 2014. Pengaruh pengawasan terhadap produktivitas kerja karyawan pabrik (Kasus Karyawan Bagian Produksi PT. Pelita Agung Agrindustri di Duri. Jurnal

Rahadian, A. H. dan Kencana, Mila. 2016. Pengaruh disiplin dan motivasi kerja pegawai terhadap efektivitas kerja penanggulangan bencana alam di Kecamatan Sukamakmur Kabupaten Bogor. Jurnal

Rahadian, A. H. Dkk. 2018. Pengaruh kompetensi pegawai dan iklim organisasi terhadap kualitas pelayanan di Unit Pelaksana Pelayanan Terpadu Satu Pintu Kota Administrasi Jakarta Barat. Jurnal

Rakhman, M. Nugrahadi. 2016. Pengaruh penilaian kinerja dan motivasi terhadap produktivitas pegawai Badan Kepegawaian Daerah Provinsi Lampung. Jurnal 